\title{
Strength properties of thermally modified softwoods and its relation to polymeric structural wood constituents
}

\author{
Michiel J. Boonstra ${ }^{\mathrm{a} *}$, Joris VAn ACKER ${ }^{\mathrm{b}}$, Bôke F. TJEerdSMA ${ }^{\mathrm{c}}$, Edo V. KEGEL ${ }^{\mathrm{a}}$ \\ a Plato International BV, PO Box 2159, NL-6802 CD Arnhem, The Netherlands \\ ${ }^{\mathrm{b}}$ Laboratory of Wood Technology, Ghent University, Coupure links 653, 9000 Ghent, Belgium \\ ${ }^{\mathrm{c}}$ SHR Hout Research, PO Box 497, 6700 AL Wageningen, The Netherlands
}

(Received 17 October 2006; accepted 18 April 2007)

\begin{abstract}
Thermal modification at relatively high temperatures (ranging from 150 to $260^{\circ} \mathrm{C}$ ) is an effective method to improve the dimensional stability and resistance against fungal attack. This study was performed to investigate the impact of heat treatment on the mechanical properties of wood. An industrially-used two-stage heat treatment method under relative mild conditions $\left(<200{ }^{\circ} \mathrm{C}\right)$ was used to treat the boards. Heat treatment revealed a clear effect on the mechanical properties of softwood species. The tensile strength parallel to the grain showed a rather large decrease, whereas the compressive strength parallel to the fibre increased after heat treatment. The bending strength, which is a combination of the tensile stress, compressive stress and shear stress, was lower after heat treatment. This decrease was less than the decrease of only the tensile strength. The impact strength showed a rather large decrease after heat treatment. An increase of the modulus of elasticity during the bending test has been noticed after heat treatment. Changes and/or modifications of the main wood components appear to be involved in the effects of heat treatment on the mechanical properties. The possible effect of degradation and modification of hemicelluloses, degradation and/or crystallization of amorphous cellulose, and polycondensation reactions of lignin on the mechanical properties of heat treated wood have been discussed. The effect of natural defects, such as knots, resin pockets, abnormal slope of grain and reaction wood, on the strength properties of wood appeared to be affected by heat treatment. Nevertheless, heat treated timber shows potential for use in constructions, but it is important to carefully consider the stresses that occur in a construction and some practical consequences when heat treated timber is used.
\end{abstract}

thermal modification / mechanical properties / cellulose / hemicelluloses / lignin

Résumé - Propriétés mécaniques de bois résineux modifiés par traitement thermique en relation avec la constitution en polymères ligneux structuraux. La modification thermique du bois à des températures relativement élevées (entre 150 et $260{ }^{\circ} \mathrm{C}$ ) présente une méthode efficace pour améliorer la stabilité dimensionnelle et la résistance aux attaques de champignons. Ce travail porte sur les effets du traitement thermique sur les propriétés mécaniques du bois. Les planches ont été soumises à un traitement thermique à des températures relativement modérées $\left(<200^{\circ} \mathrm{C}\right)$ selon un procédé industriel en deux phases. Il s'est avéré qu'un tel traitement influe nettement sur les propriétés mécaniques des bois résineux. La résistance à la traction dans la direction parallèle au fil du bois est diminuée de manière assez importante, tandis que, dans la même direction, la résistance à la compression est augmentée. La résistance au fléchissement, qui intègre la résistance aux efforts de traction, de compression et de cisaillement, était plus réduite après le traitement thermique. Cette diminution était moins importante que celle de la résistance à la traction considérée seule. La résistance aux efforts de choc a diminué de manière importante. Les tests de flexion ont permis de constater également une augmentation du module d'élasticité à la suite du traitement thermique. Des changements et/ou des modifications au niveau des principaux composants du bois semblent être impliqués dans les effets d'un traitement thermique sur les propriétés mécaniques. Les effets potentiels de dégradation et de modification d'hémicelluloses, de dégradation et/ou de cristallisation de cellulose amorphe, et de réactions de polycondensation de lignine sur les propriétés mécaniques de bois traité thermiquement ont été discutés. Le traitement thermique influait également sur l'effet de défauts naturels, tels que nœuds, poches de résine, déviations anormales du fil du bois et bois de réaction, sur les propriétés mécaniques du bois. Le bois ayant subi un traitement thermique présente malgré tout un bon potentiel en applications en structure. Néanmoins, il reste important de prendre en compte soigneusement les efforts mécaniques ainsi que quelques implications pratiques qui jouent un rôle lors de l'utilisation de bois traité thermiquement dans une construction.

modification thermique / résistance mécanique / cellulose / hémicelluloses / lignines

Normes : DIN 52186 (1978) Prüfung von Holz; Biegeversuch ; Deutsche Industrie Norm. EN 338 (1996) Structural timber - Strength classes ; European standard. EN 408 (2003) Timber structures - Structural timber and glued laminated timber - Determination of some physical and mechanical properties. EN 518 (1995) Structural timber; Grading; Requirements for visual strength grading standards. European standard.

\section{INTRODUCTION}

Although heat treatment is an effective modification method to improve the dimensional stability and resistance against

* Corresponding author: m.boonstra@platowood.nl fungal attack $[10,12,13,17,19,25,26,33,41,44]$ there are undesired side effects, mainly due to the high temperatures involved $\left(150-280^{\circ} \mathrm{C}\right)$. Reductions of mechanical properties of wood were noticed after heat treatment, e.g. the resistance to shock, modulus of elasticity (MOE), bending strength (MOR), compressive resistance, shear strength, and abrasion resistance 
$[2,14,17,28,38,41,44,47]$. A reduction of mechanical properties might limit the range of feasible applications for heat treatment technologies to wood and wood products. Therefore, it is important that a well-balanced process is applied which improves the biological durability and/or dimensional stability with no or only a slight loss of mechanical properties. In the last decade several heat treatment methods were developed and industrially applied, such as the Torrefaction and Rectification process in France [10,50], the Thermowood process in Finland [49] and the Plato process in the Netherlands [7].

This study was performed to investigate the effect of a wellestablished industrial two-stage heat treatment process [7] under relatively mild conditions $\left(<200{ }^{\circ} \mathrm{C}\right)$ on the mechanical properties of defect free and full size construction wood. Since the strength properties of wood are closely related to the chemical wood composition $[44,55]$, the effects of heat treatment on the strength properties are discussed in relation to changes of the main wood components (hemicelluloses, cellulose and lignin). Furthermore, these findings are used to elaborate on the potential to use heat treated wood in constructions.

\section{EXPERIMENTAL}

\subsection{Materials}

Radiata pine (Pinus radiata D.), Scots pine (Pinus sylvestris L.) and Norway spruce (Picea abies Karst) boards were heat treated. The standard cross section of the boards had a thickness of 25-44 mm and a width of $150 \mathrm{~mm}$. The length of the boards was approximately $3.0-5.1 \mathrm{~m}$. The moisture content of the boards before treatment was 16-20\% (shipping dry). Untreated boards were used as references for strength testing.

\subsection{Heat treatment}

For each timber species at least 10 boards were treated for each set of process conditions. The heat treatment was performed in two separate heat treatment stages and a drying stage in between. In the first stage of the heat-treatment the timber was treated in an aqueous environment at super atmospheric pressure ( $8-10 \mathrm{bar})$, a so-called hydro thermolysis treatment. This was done in a $600 \mathrm{l}$ pilot plant or in an industrial treatment vessel and the effective treatment temperature used was $165{ }^{\circ} \mathrm{C}(30 \mathrm{~min}$ effective treatment time). The treatment temperature for radiata pine boards varied between $165^{\circ} \mathrm{C}$ and $185^{\circ} \mathrm{C}$ and the treatment time applied was $0,30,45,60$ or $90 \mathrm{~min}$. The specimens were subsequently dried using a conventional drying process at $50-60{ }^{\circ} \mathrm{C}$. After drying the wood specimens were heat treated again in a special curing kiln for the second stage, now under dry and atmospheric conditions, a so-called "curing" treatment (temperature $180^{\circ} \mathrm{C}, 6 \mathrm{~h}$ effective treatment time). During this stage superheated steam or nitrogen gas was used as a sheltering gas to exclude oxygen.

\subsection{Strength and stiffness testing}

Heat treated and untreated boards were used to prepare strength test specimens, which were stored in a conditioning room $\left(20^{\circ} \mathrm{C}\right.$, $65 \% \mathrm{RH})$. Before testing the dimensions and weight of the specimens were recorded for density calculation. Furthermore small slices (10 mm thick) of treated and untreated wood were prepared to determine the moisture content using the oven-dry method $\left(104{ }^{\circ} \mathrm{C}, 16 \mathrm{~h}\right)$.
Per wood species 3 boards were selected and at least 5 specimens per board were used for the strength tests.

A stock of Scots pine boards containing a mix of sapwood and heartwood, was used for testing the different strength properties. One half of the stock was used for heat treatment and the other half was used as untreated reference. Heat treated and untreated (defect free) Scots pine specimens were prepared to determine the bending strength (DIN 52186), compressive strength (parallel and perpendicular to the grain; respectively DIN 52185 and DIN 52192), and tensile strength (parallel to the grain; DIN 52188), and Brinell hardness (parallel and perpendicular to the grain). The dimensions of the Scots pine test specimens were:

- Bending strength: cross section size $20 \times 20 \mathrm{~mm}$, length $360 \mathrm{~mm}$.

- Compressive strength parallel to the grain: cross section size $20 \times$ $20 \mathrm{~mm}$, length $30 \mathrm{~mm}$.

- Compressive strength perpendicular to the grain (radial and tangential): cross section size $20 \times 20 \mathrm{~mm}$, length $60 \mathrm{~mm}$.

- Tensile strength: width $50 \mathrm{~mm}$, depth $15 \mathrm{~mm}$, length $450 \mathrm{~mm}$. In the middle of the specimens the width and depth is limited to respectively $20 \mathrm{~mm}$ and $6 \mathrm{~mm}$ (over a length of $163 \mathrm{~mm}$ ).

- Hardness: cross section size $20 \times 20 \mathrm{~mm}$, length $60 \mathrm{~mm}$.

The bending, compressive and tensile strength of the test specimens were determined using an universal test machine TIRAtest 24100. For the Brinell hardness an iron bullet (diameter $10 \mathrm{~mm}$ ) was used, which was pressed on a defect free sample for $30 \mathrm{~s}$ with a force of $500 \mathrm{~N}$. After testing the imprint was measured and the Brinell hardness was calculated.

The impact strength of heat treated and untreated Scots pine, radiata pine and Norway spruce defect free specimens with a cross section size of $20 \times 20 \mathrm{~mm}$ and length $400 \mathrm{~mm}$, was measured according the hammer method (DIN 52189). Since the amount of boards available for testing was limited, only 10-12 defect free specimens were tested for each wood species. The treated and untreated radiata pine specimens were of the same origin, whereas the untreated Scots pine and Norway spruce specimens were randomly taken from the stock available at that time.

The bending strength and modulus of elasticity of heat treated and untreated radiata pine defect free specimens with a cross section size of $20 \times 20 \mathrm{~mm}$ and length $400 \mathrm{~mm}$, was measured on an Instron test machine according the DIN 52186, using the 4-point loading test method. The radiata pine boards which were used to prepare the test specimens, were treated at different process conditions (hydro thermolysis). In order to determine the effect of the moisture content on the bending strength and modulus of elasticity, heat treated and untreated radiata pine defect free specimens were conditioned at different relative humidity. Three treated radiata pine boards and three untreated radiata pine boards (from the same stack) were used to prepare the defect free specimens (cross section $20 \times 20 \mathrm{~mm}$; length $400 \mathrm{~mm}$ ). The radiata pine specimens were oven dried $\left(16 \mathrm{~h}, 104^{\circ} \mathrm{C}\right)$ and conditioned at $43 \%, 63 \%, 91 \%, 97 \%, 100 \%$ RH until constant weight. From each board, five specimens were taken randomly for conditioning at each relative humidity level. After conditioning, the MOR and MOE of the specimens were determined on an Instron test machine according the DIN 52186 using the 4-point loading test method.

Twelve treated and untreated Norway spruce boards were used to prepare full size specimens (cross section $40 \times 125 \mathrm{~mm}$ ) including the natural defects for a bending strength test. The untreated boards were 
Table I. Mechanical properties of heat treated and untreated Scots pine defect free specimens

\begin{tabular}{lccc}
\hline \multicolumn{1}{c}{ Properties } & & Untreated & Heat treated \\
\hline Bending strength & $\mathrm{N} / \mathrm{mm}^{2}$ & 88.7 & 85.9 \\
Stdev & $\%$ & 10.4 & 20.8 \\
MC & $\%$ & 14.8 & 4.1 \\
Density & $\mathrm{kg} / \mathrm{m}^{3}$ & 578 & 503 \\
Annual ring width & $\mathrm{mm}$ & 1.0 & 1.0 \\
Modulus of elasticity & $\mathrm{N} / \mathrm{mm}^{2}$ & 9660 & 10660 \\
\hline Compressive parallel & $\mathrm{N} / \mathrm{mm}^{2}$ & 51.3 & 65.7 \\
Stdev & $\%$ & 6.4 & 11.3 \\
MC & $\%$ & 13.5 & 4.6 \\
Density & $\mathrm{kg} / \mathrm{m}^{3}$ & 578 & 498 \\
Annual ring width & $\mathrm{mm}$ & 1.0 & 0.9 \\
\hline Compressive radial & $\mathrm{N} / \mathrm{mm}^{2}$ & 4.2 & 2.4 \\
Stdev & $\%$ & 6.9 & 30.4 \\
MC & $\%$ & 12.6 & 4.8 \\
Density & $\mathrm{kg} / \mathrm{m}^{3}$ & 580 & 531 \\
Annual ring width & $\mathrm{mm}$ & 1.0 & 0.9 \\
\hline Compressive tangential & $\mathrm{N} / \mathrm{mm}^{2}$ & 3.8 & 4.1 \\
Stdev & $\%$ & 8.4 & 13.7 \\
MC & $\%$ & 13.4 & 4.0 \\
Density & $\mathrm{kg} / \mathrm{m}^{3}$ & 598 & 566 \\
Annual ring width & $\mathrm{mm}$ & 1.0 & 0.9 \\
\hline Tensile parallel & $\mathrm{N} / \mathrm{mm}^{2}$ & 95.5 & 58.6 \\
Stdev & $\%$ & 22.5 & 37.5 \\
MC & $\mathrm{mg} / \mathrm{m}^{3}$ & 567 & 4.2 \\
Density & $\mathrm{N}$ & 36.0 & 556 \\
Annual ring width & $\mathrm{N}$ & 17.5 & 1.0 \\
\hline Hardness Parallel to grain & & & 53.2 \\
Perpendicular & & 18.4 \\
\hline & & & \\
\hline
\end{tabular}

graded into quality class C according the Dutch standard NEN $5466^{1}$. The treated and untreated boards were matched and after treatment the boards were stored in an open storage room for several months. The prepared specimens were divided into two parts of $120 \mathrm{~cm}$ (part $\mathrm{A}$ and $\mathrm{B}$ ) and weighed. The bending strength and modulus of elasticity of each part were measured on an Instron 1195 test machine according the EN 408, using the 3-point loading test method with a span of $1000 \mathrm{~mm}$.

\section{RESULTS}

In Table I, the mechanical properties of heat treated and untreated Scots pines are shown. The two-stage heat treatment clearly affects the tensile strength of the Scots pine specimens, which is strongly reduced (39\%). The two-stage heat

\footnotetext{
${ }^{1}$ Relevant features: size of round/oval knots: max. $45 \mathrm{~mm}$; dead knots allowed; knot number: no requirement; face shakes: max. $0.4 \times$ timber length per shake with a max. total length of $0.8 \times$ timber length; end shake: limited permitted allowed; bow, spring, twist and cup resp. max. 16, 8, 8 and $4 \mathrm{~mm}$ per $2 \mathrm{~m}$ timber length; slope of grain: max. 1:7; reaction wood: limited permitted; rot: not permitted; wane: not permitted; pith: permitted.
}

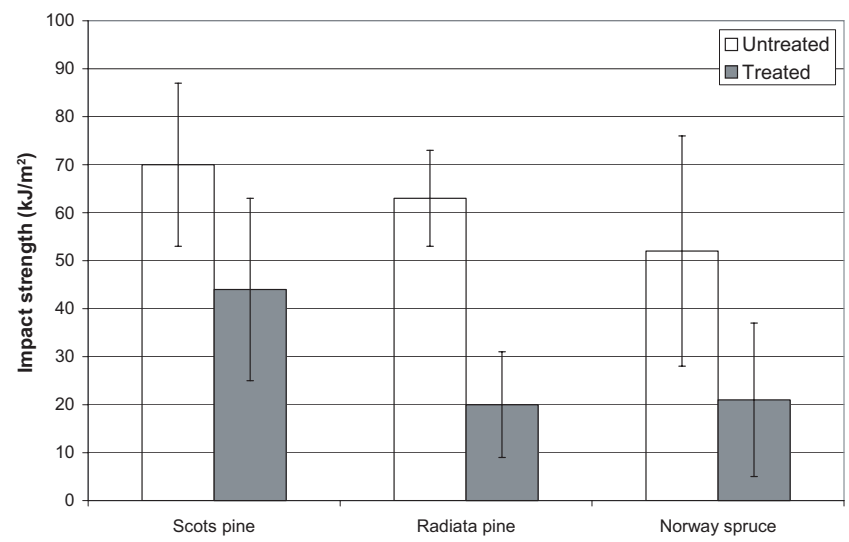

Figure 1. Impact strength of untreated and heat treated Scots pine, radiata pine and Norway spruce defect free specimens. Treatment conditions: hydrothermolysis $165^{\circ} \mathrm{C}, 30 \mathrm{~min}$; curing $180{ }^{\circ} \mathrm{C}, 6 \mathrm{~h}$.

treatment resulted in a small reduction (3\%) of the bending strength (MOR). The compressive strength parallel to the grain is clearly increased after heat treatment $(28 \%)$. The radial compressive strength is decreased (43\%) and the tangential compressive strength is slightly increased (8\%) after heat treatment. The Brinell hardness parallel to the grain is clearly increased (48\%) whereas the hardness perpendicular to the grain is slightly increased (5\%) after heat treatment. In general, the variation of the results of the different strength tests was increased after heat treatment. The Scots pine specimens showed a decrease of the density ( $2 \%$ to $14 \%$ ) whereas the modulus of elasticity during the bending test was increased (10\%).

The impact strength of Scots pine, radiata pine and Norway spruce specimens showed a decrease after heat treatment (Fig. 1). The lower impact strength of heat treated radiata pine and Norway spruce was respectively $80 \%$ and $79 \%$, while the decrease of heat treated Scots pine was less $(56 \%)$. The relative high difference in impact strength between untreated and treated Norway spruce could be due to the significant lower density of the treated specimens (respectively $515 \mathrm{~kg} / \mathrm{m}^{3}$ and $\left.372 \mathrm{~kg} / \mathrm{m}^{3}\right)$.

Heat treatment of radiata pine at $165{ }^{\circ} \mathrm{C}$ (effective hydro thermolysis temperature) resulted in a decrease of the bending strength (9\%) and an increase of the modulus of elasticity (13\%) (Fig. 2). An increase of the effective treatment temperature to $185^{\circ} \mathrm{C}$ during the hydro thermolysis stage resulted in a further reduction of the bending strength (38\%). The absence of a dwell time (effective treatment time) during a treatment at $175^{\circ} \mathrm{C}(0 \mathrm{~min}$ dwell time $)$ did not result in a higher bending strength than the treatment with a dwell time of $30 \mathrm{~min}$. Remarkable is the increase of the MOE (26\%) of the radiata pine specimens when the hydro thermolysis treatment temperature was raised to $175^{\circ} \mathrm{C}$ ( 0 min dwell time) and the successive decrease of the MOE $(-2 \%)$ of the radiata pine specimens when treated at $175^{\circ} \mathrm{C}(30$ min dwell time $)$ and treated at $185{ }^{\circ} \mathrm{C}$. An increase of the dwell time during a hydro thermolysis at $165{ }^{\circ} \mathrm{C}$ (30 to $\left.90 \mathrm{~min}\right)$ resulted in a further reduction (20\%) of the bending strength (Fig. 3). Although there is no difference in the average bending strength between an effective treatment 


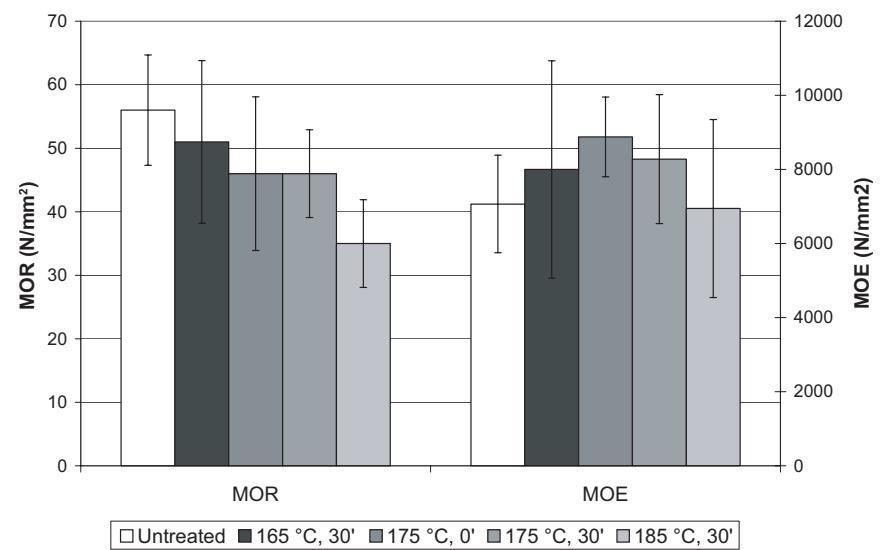

Figure 2. Effect of the hydro thermolysis temperature on the bending strength (MOR) and Modulus of Elasticity (MOE) of heat treated radiata pine defect free specimens. Curing: $180^{\circ} \mathrm{C}, 6 \mathrm{~h}$.

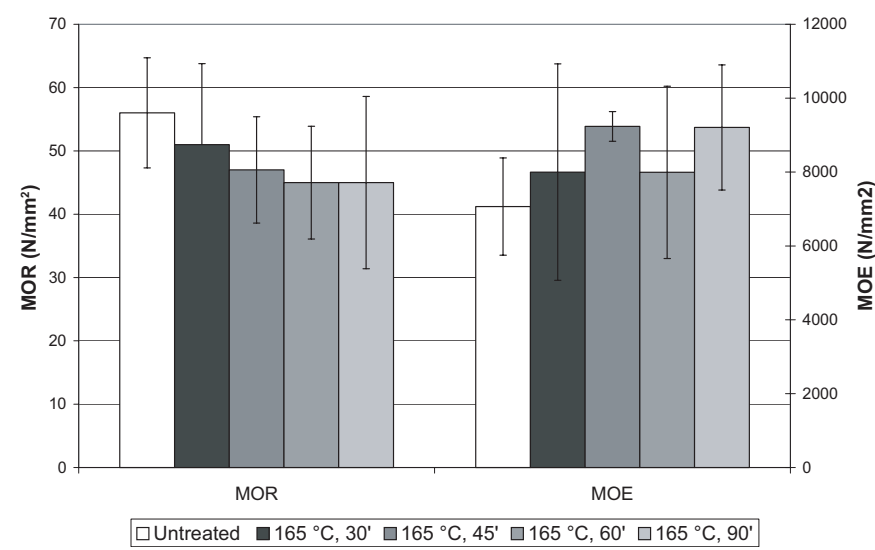

Figure 3. Effect of the hydro thermolysis process time on the bending strength (MOR) and Modulus of Elasticity (MOE) of heat treated radiata pine defect free specimens. Curing: $180^{\circ} \mathrm{C}, 6 \mathrm{~h}$.

time of 60 and $90 \mathrm{~min}$, the variation in test results of the radiata pine specimens treated for $90 \mathrm{~min}$ is higher than that of the specimens treated for $60 \mathrm{~min}$ indicating some differences. The MOE appears to increase when the effective treatment time is increased to $90 \mathrm{~min}$.

The bending strength and modulus of elasticity of untreated and heat treated radiata pine, conditioned at different relative humidity are given in Figures $4 \mathrm{a}$ and $4 \mathrm{~b}$. The moisture content of the specimens at the different relative humidity is given in Figure 5 which shows the typical hysteresis of wood (including heat treated wood). The bending strength of untreated and treated radiata pine decreases with increasing moisture content. The bending strength of radiata pine conditioned at 63\% RH (and lower) decreased clearly after heat treatment. Remarkable is therefore the difference in MOR between untreated and heat treated radiata pine conditioned at a relative humidity of $91 \%, 97 \%$ and $100 \%$ RH. At a high moisture content there is nearly no difference in MOR. Radiata pine showed an increase in MOE after heat treatment and the moisture content of the specimens appeared not to affect this difference.
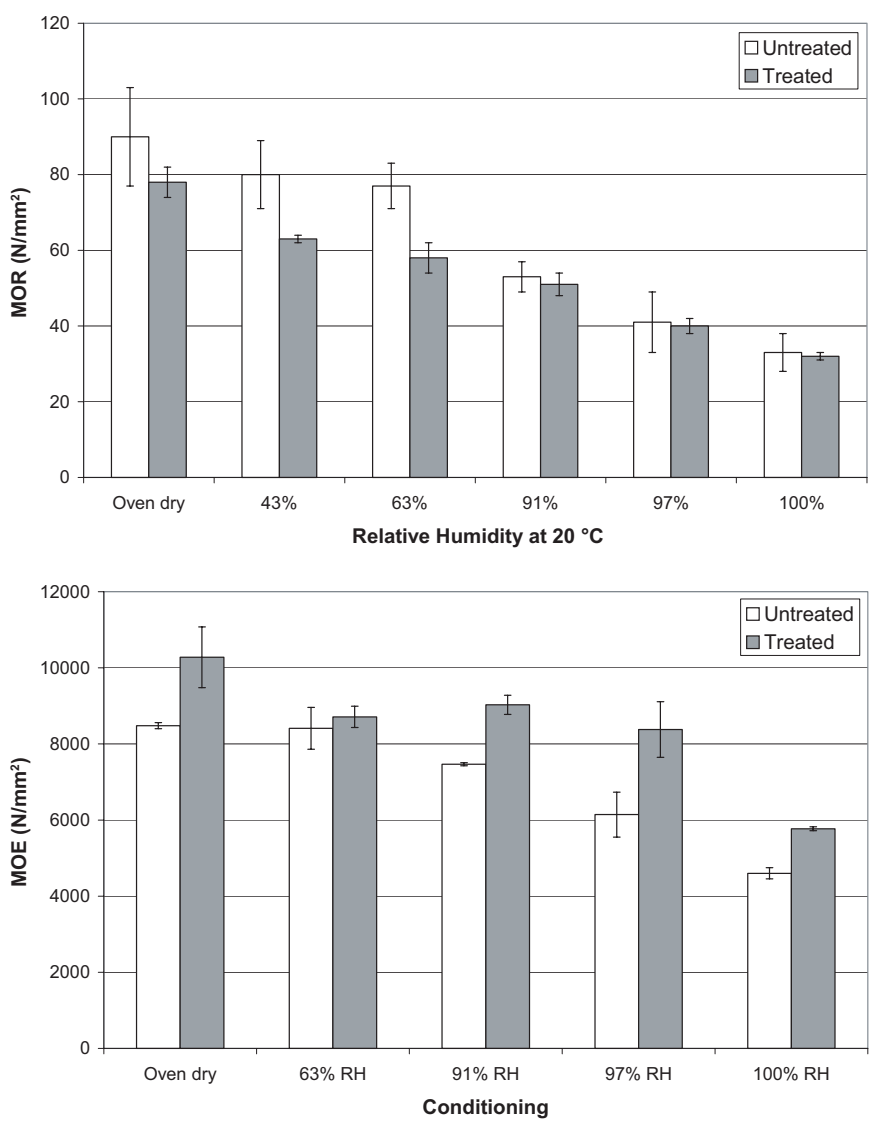

Figure 4. Effects of conditioning on the bending strength (a) and Modulus of Elasticity (b) of heat treated and untreated radiata pine specimens (defect free). Treatment conditions: hydrothermolysis $165^{\circ} \mathrm{C}, 30 \mathrm{~min}$; curing $180^{\circ} \mathrm{C}, 6 \mathrm{~h}$.

Several effects of heat treatment on the wood quality of full size Norway spruce boards have been noticed, such as cracks (internal, on the surface and at the board ends) and deformation (twist, bow, spring). Furthermore, large knots (> $20 \mathrm{~mm}$ ) were broken or showed rather large fissures. Resin pockets were 'opened' and the size appeared to be increased after heat treatment. The density, bending strength and modulus of elasticity of the full size Norway spruce boards including natural defects are shown in Table II (the averages of part A and B of each board are shown). Heat treatment resulted in a decrease of the density $(-9 \%)$ and bending strength $(-31 \%)$, whereas the modulus of elasticity increased after heat treatment $(+5 \%)$. The variation in the bending test (MOR and MOE) appeared to be rather similar for treated and untreated boards. A clear difference of the maximum displacement at failure between untreated and heat treated Norway spruce boards was noticed. Untreated Norway spruce boards failed at 24 to $40 \mathrm{~mm}$, whereas the heat treated Norway spruce boards failed at a displacement of 10 to $24 \mathrm{~mm}$ (span $1000 \mathrm{~mm}$, cross section size $40 \times 125 \mathrm{~mm}$ ). At failure the treated Norway spruce boards showed an important and abrupt fracture. Untreated Norway spruce boards showed a more gradual decrease. The boards are tougher than the somewhat brittle treated boards. 


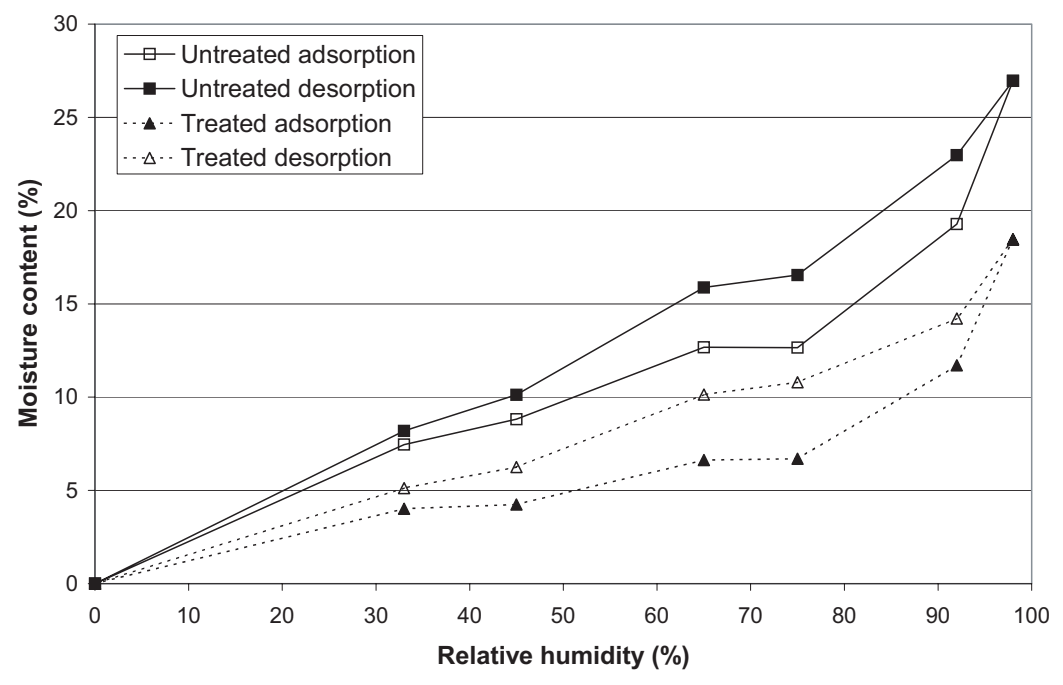

Figure 5. Moisture content of untreated and heat treated radiata pine conditioned at different relative humidity (hysteresis). Treatment conditions: hydrothermolysis $165^{\circ} \mathrm{C}, 30 \mathrm{~min}$; curing $180^{\circ} \mathrm{C}, 6 \mathrm{~h}$.
Table II. Density, bending strength and modulus of elasticity of full size treated and untreated Norway spruce boards (cross section $40 \times$ $125 \mathrm{~mm})$.

\begin{tabular}{lccc}
\hline Properties & & Untreated & Treated \\
\hline Moisture content & $\%$ & 14 & 6 \\
\hline Density & $\mathrm{kg} / \mathrm{m}^{3}$ & 434 & 397 \\
Stdev & $\%$ & 5.7 & 5.3 \\
Min & $\mathrm{kg} / \mathrm{m}^{3}$ & 390 & 356 \\
Max & $\mathrm{kg} / \mathrm{m}^{3}$ & 484 & 431 \\
\hline Bending strength & $\mathrm{N} / \mathrm{mm}^{2}$ & 57.2 & 39.3 \\
Stdev & $\%$ & 12.3 & 21.9 \\
Min & $\mathrm{N} / \mathrm{mm}^{2}$ & 46.6 & 21.9 \\
Max & $\mathrm{N} / \mathrm{mm}^{2}$ & 69.8 & 53.9 \\
Displacement at failure & $\mathrm{mm}$ & $24-40$ & $10-24$ \\
\hline Modulus of Elasticity & $\mathrm{N} / \mathrm{mm}^{2}$ & 10669 & 11225 \\
Stdev & $\%$ & 10.6 & 8.3 \\
Min & $\mathrm{N} / \mathrm{mm}^{2}$ & 9042 & 8944 \\
Max & $\mathrm{N} / \mathrm{mm}^{2}$ & 12131 & 12187 \\
\hline
\end{tabular}

In Figures 6, 7 and 8 the test results are shown of the individual Norway spruce boards which were used for the bending test. There appears to be no clear relationship between the density and bending strength of untreated and heat treated Norway spruce boards. In Figure 7 the modulus of elasticity of treated and untreated boards is shown for different densities. The $R^{2}$ of untreated and especially treated Norway spruce boards is higher (respectively 0.034 and 0.250 ) indicating a limited dependency on density differences. There appears to be a clear relationship between the bending strength and the modulus of elasticity, especially for the untreated Norway spruce boards (Fig. 8).

\section{DISCUSSION}

The main polymeric components of the cell wall (cellulose, hemicelluloses en lignin) contribute in different degrees to the strength of wood as proposed in a hypothetical model by Rowell and Winandy [55]. They suggest that mechanical properties, which relates to internal stress and strain, are simply functions of chemical bond strength: covalent and hydrogen intrapolymer bonds (molecular level); covalent and hydrogen interpolymer bonds and cell wall layer bonds (microscopic level); and fiber-to-fiber bonding with the middle lamella acting as the adhesive (macroscopic level). According to Sweet and Winandy [45] wood fibres can be regarded as a composite material and a single micro fibril or a group of microfibrils cannot entirely account for the strength of an entire wood fibre. The chemical-mechanical linkages between cellulose microfibrils and the lignin-hemicelluloses matrix allow load sharing among the microfibrils. They suggest that internal stresses can be distributed across the cell wall and throughout the entire fibre, if the cellulose microfibrils and the lignin-hemicelluloses act as a continuum. Whistler and Chen [51] suggested that hemicelluloses and microfibrils are closely associated by intermixing (i.e. physical entanglement at molecular level) which might also contribute to the distribution of internal stresses.

Any chemical or thermal modification methods that affect the individual wood components and their interaction must therefore affect the mechanical properties of wood [36]. Heat treatment, such as the two-stage treatment method used in this study, causes a modification of the main components and changes the chemical composition of wood as described in previous studies $[6,35,46,48]$ and by several other authors $[4,10,13,16,37,39,41,43,44]$. In the moist treatment stage, the hydro-thermolysis, hemicelluloses are depolymerized by hydrolysis reactions to oligomers and monomers. This involves cleavage of the sidechain constituents (arabinose and galactose), followed by degradation of the main chain constituents (mannose, glucose and xylose). The corresponding pentoses and hexoses are dehydrated to respectively furfural and hydroxymethylfurfural. Cleavage of acetic acid from acetyl side chains of hemicelluloses occurs. Hydronium ions generated by water autoionization are thought to act as catalysts in the initial reaction stages. In further reaction stages, the hydronium ions generated from acetic acid autoionization (and possibly 

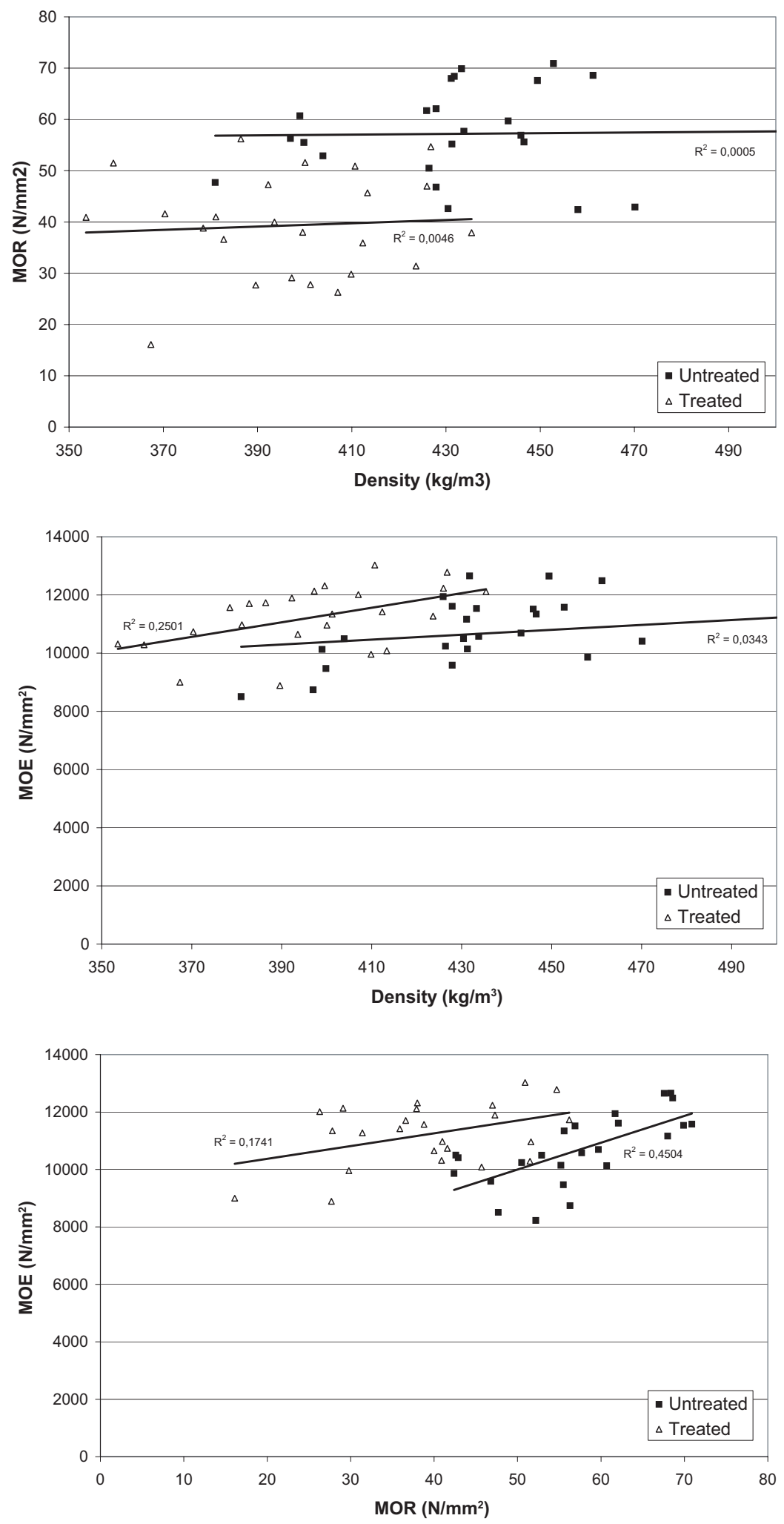

Figure 6. Bending strength (MOR) for different density of full size Norway spruce boards (cross section $40 \times$ $125 \mathrm{~mm})$, treated and untreated.

Figure 7. Modulus of elasticity (MOE) for different density of full size Norway spruce boards (cross section $40 \times 125 \mathrm{~mm}$ ), treated and untreated.

Figure 8. Correlation between the bending strength and modulus of elasticity of full size Norway spruce boards (cross section $40 \times 125 \mathrm{~mm}$ ), treated and untreated. 
some other acids such as levulinic and formic acid) also acts as catalysts and their contribution will be more important than that of water autoionization. Degradation of cellulose is expected to be limited since the temperatures used during this heat treatment are too low (at temperatures below $210-220^{\circ} \mathrm{C}$ only little cellulose degradation occurs). Heat treatment under moist conditions, such as the hydrothermolysis stage, appears to have a stimulating effect on the crystallization of amorphous cellulose [3]. An increase of the relative amount of crystalline cellulose is thus observed, but it is a question whether this is due to the degradation or to the crystallization of amorphous cellulose (or both). During the hydro-thermolysis stage lignin can be subject to degradation, but also to repolymerization reactions. The covalent bonds between lignin and hemicelluloses will be broken and low molecular weight lignin fragments with high reactivity are produced. Condensation reactions of such products probably result in repolymerization and it is thought that degradation products of hemicelluloses (e.g. furfural) are also involved [16]. This can result in new lignin based polymers [16] and/or in an increased cross-linking of the existing lignin network $[4,13,43,48]$. The formation of a lignin-cellulose complex due to condensation reactions has also been suggested [27]. Since condensation reactions are relatively slow a second heat treatment stage is performed which enables further repolymerization and/or cross linking. This relatively long treatment stage is performed under dry and atmospheric conditions at a very low oxygen level. Degradation of lignin or cellulose during this treatment stage is expected to be very limited.

Below the effects of this heat treatment on physical and strength properties of softwoods are discussed in relation to the chemical composition of heat treated wood.

\subsection{Physical properties}

Heat treatment of wood resulted in a significant reduction in water adsorption (Fig. 5). The availability and/or accessibility of the free hydroxyl groups of the wood carbohydrates play an important role in the process of water adsorption and desorption [6]. It is by no doubt that heat treatment results in a reduction of the accessible, free hydroxyl groups and several causes are reported, e.g. depolymerisation of the carbohydrates and especially hemicelluloses causing a reduction of the total amount of hydroxyl groups, including the free hydroxyl groups $[13,26]$; an increase of the relative proportion of the crystalline cellulose, in which the hydroxyl groups are not easily accessible to water molecules $[35,48]$; and crosslinking of the lignin network $[4,13,48]$ which might hinder the accessibility of free hydroxyl groups to water [34].

It is well known that bound water strongly affects the strength properties of wood. Increased amounts of bound water interfere with and reduce hydrogen bonding between the organic polymers of the cell wall and thereby decrease the strength properties of wood since strength is related to covalent but also to hydrogen intrapolymer bonds $[15,55]$. Heat treatment must therefore have a positive contribution to the strength properties since heat treated wood is less hydrophobic and the (maximum) amount of bound water is reduced (Fig. 5). Such an effect is shown in Figure 4a. An increase of the moisture content of treated and untreated radiata pine resulted in a reduction of the bending strength. This reduction is clearly lower for treated radiata pine and at a very high relative humidity (91-100\%) the difference in MOR between treated and untreated radiata pine is very limited.

A material property which is clearly altered during heat treatment is the weight of the boards and thus the density of wood (Tabs. I and II). The main reasons for the decrease of the density of wood after heat treatment are: degradation of wood components (mainly hemicelluloses) into volatile products which evaporate during treatment; evaporation of extractives; and a lower equilibrium moisture content of the boards since heat treated wood is less hydrophobic. Although lower density after heat treatment implicates decrease of the strength properties [53,55], this conclusion can be premature. Degradation of the main wood components with its corresponding loss in woody material and weight, decreases strength properties since the internal stresses must be distributed over less molecular material. On the other hand, lower moisture content does have a positive effect on the strength properties reducing the effect of weight loss (Fig. 4a).

\subsection{Tensile strength}

With regard to the three primary stresses it is probably the tensile strength which is affected the most by heat treatment, at least at ultimate strength levels (Tab. I). Originally cellulose was thought to be primarily responsible for the (tensile) strength of wood and in particular of wood fibres [24, 44]. When tensile stresses occur in wood the cellulose microfibrils and/or fibrils are sliding and pulling one from another which must require breaking of covalent bonds. Degradation (e.g. depolymerisation) of the cellulose polymer, decreasing the DP, was suggested to be the main cause for tensile strength losses $[22,23,30,55]$.

Heat treatment results in a small but noticeable degradation of amorphous cellulose causing some disturbance and/or depolymerisation of the cellulose polymer [6]. This could be a reason for the observed decrease of the tensile strength. However, according to Stamm [44] internal stresses are distributed among several cellulose microfibrils/fibrils. Furthermore, the effect of the cellulose polymer length on the strength is limited since the tensile strength is not changing at DP's over 300. Whether or not the crystallization of amorphous cellulose is involved is not clear. Crystalline cellulose with its highly ordered and rigid structure might break more easily than amorphous cellulose which appears to be more flexible. Therefore, an increase of the amount of crystalline cellulose might have a negative impact on the tensile strength.

Degradation of hemicelluloses during heat treatment might also be involved in the decrease of the tensile strength. The main effects of hemicelluloses degradation appears to be: cleavage of the secondary bonds (hydrogen and Van der Waals bonds, physical entanglement) within the hemicellulosic polymer; cleavage of the secondary bonds between the 
hemicelluloses and cellulose; and cleavage of the covalent bonds between hemicelluloses and lignin. These effects disrupt the load-sharing capacity of the lignin-hemicelluloses matrix in which the cellulose microfibrils and/or fibrils are encrusted [29]. A cellulose micro fibril/fibril cannot or to a lesser extent share forces with the next micro fibril/fibril.

It is not expected that changes of lignin during heat treatment are involved in the decrease of the tensile strength. According to Winandy and Rowell [55], it must be the carbohydrate framework which causes failure since the strength of the lignin network is high enough to resist internal stresses. Further cross linking of the lignin network probably increases the strength of this polymer.

An anatomical study of heat treated wood revealed limited effects on the macrostructure, depending on the wood species used and the process method or conditions applied [8]. Broken cell walls perpendicular to the grain resulting in transverse ruptures have been noticed in treated softwood and hardwood species. This contributes to abrupt fractures of treated wood as observed in bending or tensile strength tests, which can lead to considerably different failure behaviour.

\subsection{Compressive strength}

Remarkable is the anisotropic effect of heat treatment on the compressive strength and hardness (Tab. I). In longitudinal direction the compressive strength increased clearly, while in the radial and tangential direction a decrease (radial) or small increase (tangential) was noticed. The increase of the compressive strength in longitudinal direction might be due to a lower amount of bound water in heat treated wood, however it is expected that the amount of bound water must be higher to affect the strength properties (Fig. 4a). During heat treatment the amount of the highly ordered crystalline cellulose increases due to degradation and/or crystallization of amorphous cellulose. Since crystalline cellulose shows significant anisotropy, its stiff and rigid structure might be responsible for the observed increase of the compressive strength in longitudinal direction. However, the increase of crystalline cellulose after the two-stage heat treatment is rather small [6] and its effect on the compressive strength might be limited. An increased cross linking of the lignin polymer network could be another reason for this improvement. Lignin acts as a stiffener of the cellulose microfibrils/fibrils [45] and an increased cross linking of this polymer appears to prevent or limit movement perpendicular to the grain (which occurs during compressive loading parallel to the grain). Furthermore, lignin is the main component of the middle lamella [15] and an increased cross linking of the lignin polymer network improves the strength of the middle lamella which subsequently affects the strength properties of the cell wall. This can be an indication that the lignin polymer network contributes directly to the strength of wood. Findings of Banoub and Delmas [1] indicating a regular structure within the lignin polymer network support this statement, since regular structures are expected to add a constructive contribution to the strength of wood.
The compressive strength and hardness perpendicular to the grain (radial and tangential) is much lower than parallel to the grain (longitudinal). The presence of different types of bonds, strong and stiff bonds along the chain axis and weak and soft secondary bonds acting in the transverse directions; and orientation of the polymer molecules in wood, such as micro fibril angle of the crystalline cellulose and/or a rather regular structure of the lignin polymer network, are thought to be the main cause for this anisotripic difference [55]. In the radial and tangential direction the effect of the cellulose microfibrils/fibrils on the compressive strength is thus limited compared to the longitudinal direction, due to the anisotropic character of cellulose. Changes within the lignin-hemicelluloses matrix after heat treatment might have a more prominent effect on the compressive strength in transverse directions. Degradation of the hemicelluloses reducing the load sharing capacity of the lignin-hemicelluloses matrix probably has a negative impact on the compressive strength. An increased cross linking of the lignin polymer network could have a positive effect on the compressive strength. However, it appears that the effects of such changes are rather limited since the compressive strength and hardness is not changed after heat treatment, at least in tangential direction. The decrease of the radial compressive strength after heat treatment might be caused by small radial fissures which were noticed in Scots pine after heat treatment [8].

\subsection{Shear strength}

Unfortunately no tests were performed to determine the effect of the two-stage heat treatment on the shear strength of wood. In other studies a reduction of the shear strength has been found after heat treatment and according to Stamm [44] this can be explained by the (partial) conversion of the polyoses, which make up about $20 \%$ of the middle lamella, into furfural polymers. Such degradation of the hemicelluloses reducing the load sharing capacity between cellulose microfibrils/fibrils, most probably have a negative impact on the shear strength. On the other hand, an increased cross linking within the lignin polymer network could have a positive effect on the shear strength, especially because lignin is the main component of the middle lamella which plays an important role in shear strength. On the macrostructure level there is an indication that heat treatment must affect the shear strength [8]. Softwood species with narrow annual rings and/or an abrupt transition from earlywood into latewood were sensitive for tangential cracks in the latewood section. Radial cracks were also observed, mainly in wood species with an impermeable wood structure such as Norway spruce. Such defects can lead to a faster and/or increased failure when external forces, causing internal shear stresses, are applied on wood.

\subsection{Bending and impact strength}

In the bending test the specimens are loaded with an increasing force during several minutes until failure occurs. The 
internal stresses which occur during bending are a combination of the compressive stress (topside of the specimens), tensile stress (lower side of the specimens) and shear stress (middle of the specimens). Although the decrease of the tensile strength and probably the shear strength was rather large the bending strength showed only a slight reduction after heat treatment of Scots pine (Tab. I). Therefore, the influence of the individual primary stress type on the bending strength appears to be limited.

There appears to be a relationship between the decrease of the bending strength and the degradation of the hemicelluloses $[23,29,52]$ and it has been suggested that changes in the hemicelluloses content and structure are primarily responsible for the initial loss of the bending strength $[45,54]$, since hemicelluloses are the most thermal-chemically sensitive component of wood [25]. Raising the effective treatment temperature and/or increasing the treatment time during the hydro-thermolysis stage resulted in a further decrease of the bending strength (Figs. 2 and 3). It has also been found that more severe process conditions during this process stage resulted in a further degradation of the hemicelluloses [6] confirming a possible relationship. LeVan [29] proposed that cleavage of the sidechains of hemicelluloses within the ligninhemicelluloses matrix caused disruption of load-sharing capacity and therefore might be responsible for the observed strength losses. Another explanation which is given for the observed initial strength loss was a reduction of the DP of hemicelluloses, which means a degradation of the hemicelluloses backbone. In this case the hemicelluloses must contribute directly to the strength of the wood fibre, more than previously was assumed. It is however rather hypothetical whether a polymer of such short DP and situated around the (amorphous) cellulose microfibrils, can contribute in this way to the strength of wood fibres. It appeared that cellulose and lignin were not affected until strength losses exceeded 30-40\% [45, 54], since no depolymerisation or degradation products of these polymers were observed. However, the possibility of rearrangements of the molecular structure of cellulose and/or lignin, and its effects on the strength properties of wood, were not considered (e.g. reorientation and/or crystallisation of cellulose, polycondensation reactions of lignin). Furthermore, the bending strength is a combination of the primary internal stresses in wood which are the tensile, compressive and shear stress. No specification was made how these primary stresses were affected when hemicelluloses were degraded. It is thus rather unclear in what way the bending strength is affected and more research is necessary including precise mechanical testing and detailed chemical analysis on wood specimens treated in various temperature-moisture conditions.

Remarkable for the treated specimens is the abrupt failure during the bending test which is more gradual for untreated specimens. The energy consumed up to total fracture is lower for the treated specimens than for the untreated specimens. The external forces heat treated wood can bear after failure are much lower than for untreated wood. Broken cell walls perpendicular to the grain appears to be the cause for this phenomenon as described above, although changes of the main wood components might also be involved, especially degrada- tion of the carbohydrates and/or crystallization of amorphous cellulose (making wood more brittle).

The relative large decrease of the bending strength of radiata pine after heat treatment (Figs. 2 and 3) might be related to the occurrence of a relative large amount of juvenile wood in radiata pine [21]. The chemical composition of juvenile wood differs from mature wood with a higher hemicelluloses and lignin content [19]. The composition of the hemicelluloses also changes from the pith outwards over the first 20 growth rings (decrease of galactose, xylose and arabinose content and an increase of the mannose content). A higher hemicelluloses content and/or a different composition of the hemicelluloses affects the chemical reaction mechanism during heat treatment and subsequently the strength properties can be affected as discussed above. Differences between juvenile and mature wood in the anatomical and ultrastructural characteristics might also result in different strength properties after heat treatment. The larger microfibrillar angle of juvenile wood resulting in a higher longitudinal and lower transverse shrinkage [19] might cause internal stresses in wood affecting strength properties, especially since the specimens are almost completely dried during the curing stage (maximal shrinkage).

In the impact strength test the specimens are loaded during a very short period (a few milliseconds) with a rather high force. Heat treatment resulted in a large reduction of the impact strength (Fig. 1), especially when compared to the decrease of the bending strength. According to Davis and Thompson [14] degradation of hemicelluloses is mainly responsible for the decrease of toughness. Since the interaction between cellulose and hemicelluloses are based on secondary bonds, this implicates that it must be cleavage of these secondary bonds which determines the impact strength. However, based on the rather high decrease of the impact strength it must also be cleavage of covalent bonds during heat treatment which contributes to this decrease. Cleavage of covalent bonds between hemicelluloses and lignin might be involved but also the cleavage of covalent bonds within the cellulose microfibrils/fibrils (depolymerization). An increase of the amount of crystalline cellulose due to degradation and/or crystallization of amorphous cellulose might also have a negative impact on the impact strength as discussed above (tensile strength).

\subsection{Modulus of elasticity}

The effects of heat treatment on the elastic properties of wood are rather limited, although an increase of the MOE during the bending test has been noticed (Tab. I, Figs. 2, 3 and 4). Degradation of the hemicelluloses, disrupting the load-sharing capacity of the lignin-hemicelluloses matrix, and increase of the relative amount of crystalline cellulose could contribute to the increase of the MOE. The increased cross linking of the lignin network probably also affects the MOE, since it is expected that an increased cross linking improves the rigid structure around the cellulose microfibrils/fibrils and the strength characteristics of the middle lamella. Furthermore, heat treated wood is less hygroscopic than untreated wood (it contains less bound water in the cell wall), which affects the MOE making wood less pliable. The decrease of the correlation $\left(R^{2}\right)$ 
between the bending strength and the MOE (Fig. 8) are probably due to different effects of heat treatment as discussed above.

Another phenomenon which can affect the strength properties of wood after heat treatment is the thermoplastic properties of wood [18, 20,21,42]. Above a certain temperature the physical characteristics of hemicelluloses $\left(127-235^{\circ} \mathrm{C}\right)$, lignin $\left(167-217^{\circ} \mathrm{C}\right)$ and the cellulose $\left(231-253^{\circ} \mathrm{C}\right)$ changes into a rubbery or plastic state. Thermal softening of wood as a whole occurs at temperatures over $200{ }^{\circ} \mathrm{C}$, although steaming reduces the softening point $\left(180^{\circ} \mathrm{C}\right)$ since water acts as a plasticizer. The thermal behaviour of lignin and hemicelluloses seems to be restricted by interactions due to secondary intermolecular bonding with the cellulose [20,42]. Degradation of the hemicelluloses during the hydro-thermolysis stage affects these secondary bonding which enables the plastizication of the remaining hemicelluloses and lignin. In the cooling down phase these components become rigid again and the molecular polymer structure might be changed [5]. This probably affects the interaction between the main components of wood affecting the strength properties.

\subsection{Effect of natural defects on strength properties}

Testing of defect free specimens is a good method to compare the effects of different treatment processes and/or different treatment conditions. However, results of tests cannot be used for the calculation of constructive elements, at least not without the use of several safety factors $[11,24,31,32]$. The occurrence of natural defects in wood, such as knots, resin pockets, reaction wood and an abnormal slope of grain, decreases the strength properties of timber. A clear example is the bending strength of full size Norway spruce boards which is significant lower than the bending strength of defect free specimens (Fig. 9) ${ }^{2}$.

Heat treatment appeared to affect the influence of natural defects on the strength properties of wood. The bending strength of full size Norway spruce boards showed a clear decrease $(-31 \%)$ after heat treatment (Fig. 9), whereas this effect appeared to be less obvious $(-7 \%)$ for defect free specimen [29]. During heat treatment (curing stage) the boards were dried to very low moisture content $(0-1 \%)$ with a corresponding maximal shrinkage. This can cause deformation, especially when reaction wood or juvenile wood is present. Furthermore, shrinkage of knots differs from the surrounding wood causing internal stresses between the wood fibres situated around the knots. This affects the macrostructure of wood and subsequently the mechanical properties of the timber.

A large scale bending test with heat treated posts $(66 \times$ $66 \mathrm{~mm}$ ) showed that the bending strength and MOE was particularly low for treated posts with a combination of several natural defects, e.g. large knots, enclosed pith and an abnormal slope of grain [9]. This was less obvious for untreated

\footnotetext{
2 The values of defect free specimens are based on a study by Scheiding et al. [40] in which Norway spruce boards were treated according the two-stage heat treatment method, and treated and untreated defect free specimens were tested according the 4-point loading test method.
}

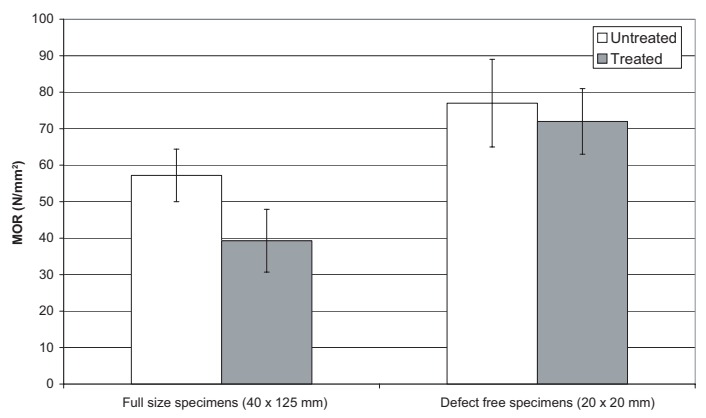

Figure 9. Bending strength of heat treated and untreated Norway spruce, full size versus defect free specimens.

posts confirming a relationship between the wood quality and strength properties after heat treatment.

Based on the strength properties of full size timber as found in this study, it is clear that heat treated timber shows potential for use in constructions. Heat treatment improves the durability and dimensional stability of wood which are important factors for applications under higher biological hazard circumstances and therefore have an impact on the mechanical properties of timber. However, the application and the typical forces which occur in a construction should be considered carefully taking into account the typical strength characteristics and failure behaviour of heat treated wood (e.g. tensile strength and abrupt fractures of heat treated timber). On the other hand, improved strength properties like compressive strength, hardness and stiffness might favour the use of heat treated wood for certain applications.

There are still relevant questions which should be considered if heat treated wood is used for constructions, e.g.:

- What is the effect of heat treatment on the strength class of timber?

- What is the long-term behaviour of heat treated wood? and

- How does heat treated wood respond to cyclic or repeated loadings?

It is a question whether visual grading (according EN 518) or stress grading (based on non-destructive bending or ultrasonic sound methods) are suitable for heat treated timber. Heat treatment showed a different effect on the natural defects of wood in relation to the strength properties affecting visual grading. Since the relationship between the bending strength and the MOE is rather poor (Fig. 8), stress grading appeared not very suitable for heat treated wood. A combination of several methods, such as visual grading and non-destructive stress grading, might result in a better prediction of the bending strength and subsequently the strength class.

An alternative is to grade the boards before heat treatment, but then the effect of heat treatment on the strength class of a timber species should be verified. This includes effects on the strength characteristics of timber, such as bending strength (5\% characteristic value) and modulus of elasticity (average and $5 \%$ characteristic value), but also the effect on the compressive, tensile and shear strength which are not commonly tested when the strength class is determined (according EN 
338). Especially the tensile strength can be of importance, depending on the application, since heat treatment shows a major impact on this strength characteristic.

Important test variations for constructive applications of heat treated wood which are still unknown are time dependant and impact of repeated loadings. The ability of wood to resist stresses is dependent upon the duration of load and the strength tests performed in this study reflect a rather shortterm loading. Heat treated wood might also respond different to cyclic or repeated loadings which often induce fatigue failures. The stress levels necessary to cause such failures are far lower (25-30\%) than those required to cause static failure [55]. According to Winandy and Rowell [55] repeated or fatiguetype stresses usually result in a slow thermal build-up within the material and initiate and propagate tiny microchecks that eventually grow to a detrimental size. It can be of importance to know what the characteristics of heat treated wood are when subjected to cyclic or repeated loadings.

\section{CONCLUSION}

Heat treatment revealed a clear effect on the mechanical properties of softwood species. The tensile strength parallel to the grain showed a rather large decrease, whereas the compressive strength parallel to the fibre increased after heat treatment. The bending strength, which is a combination of the tensile stress, compressive stress and shear stress, was lower after heat treatment. This decrease was less than the decrease of only the tensile strength. The impact strength showed a rather large decrease after heat treatment. An increase of the modulus of elasticity during the bending test has been noticed after heat treatment. Changes and/or modifications of the main wood components appear to be involved in the effects of heat treatment on the mechanical properties. The possible effect of degradation and modification of hemicelluloses, degradation and/or crystallization of amorphous cellulose, and polycondensation reactions of lignin on the mechanical properties of heat treated wood are discussed. Since the effects of such chemical changes on the internal stresses and subsequently the strength of wood are complicated more research is necessary including precise mechanical testing and detailed chemical analysis on wood specimens treated in various temperaturemoisture conditions.

The effect of natural defects, such as knots, resin pockets, abnormal slope of grain and reaction wood, on the strength properties of wood appeared to be affected by heat treatment. Nevertheless, heat treated timber shows potential for use in constructions. Since MOE is often the most critical parameter for a construction, higher stiffness results in lower deflection for a given load, heat treatment appears not to lower the potential for constructive applications. It is, however, important to carefully consider the stresses that occur in a construction and some practical consequences when heat treated timber is used as the impact of heat treatment on different strength properties is not proportional. Furthermore more test work is required to study the effect of heat treatment on long-term and repeated loadings, for indoor and outdoor conditions.
Acknowledgements: The authors wish to thank the Institute für Holz- und Papiertechnik of the Technical University of Dresden for doing parts of the test work.

\section{REFERENCES}

[1] Banoub J.H., Delmas M., JMS letters, J. Mass Spectrom. 38 (2003) 900-903.

[2] Bekhta P., Niemz P., Effect of high temperature on the change in colour, dimensional stability and mechanical properties of spruce wood, Holzforschung 57 (2003) 539-546.

[3] Bhuiyan M.T.R., Hirai N., Changes in crystallinity in wood cellulose by heat treatment under dried and moist conditions, J. Wood Sci. 46 (2000) 431-436.

[4] Bobleter O., Binder H., Dynamischer hydrothermaler Abbau von Holz, Holzforschung 34 (1980) 48-51.

[5] Boonstra M.J., Blomberg J., Semi-isostatic densification of heat treated radiata pine, Wood Sci. Technol. 7 (2007) DOI: 10.1007/s00226-007-0140-y.

[6] Boonstra M.J., Tjeerdsma B.F., Chemical analysis of heat treated softwoods, Holz Roh.-Werkst. 64 (2006) 204-211.

[7] Boonstra M.J., Tjeerdsma B.F., Groeneveld H.A.C., Thermal modification of non-durable wood species. Part 1. The Plato technology: thermal modification of wood, International Research Group on Wood Preservation, Document No. IRG/WP 98-40123, 1998.

[8] Boonstra M.J., Rijsdijk J.F., Sander C., Kegel E., Tjeerdsma B.F., Militz H., Van Acker J., Stevens M., Microstructural and physical aspects of heat treated wood. Part 1. Softwoods, Maderas Ciencia y tecnología 8 (2006) 193-208.

[9] Boonstra M.J., Van Acker J., Kegel E., The effect of a two-stage heat treatment process on the mechanical properties of full size Norway spruce posts, submitted to Wood Mat. Sci. Eng. (2007).

[10] Bourgois J., Guyonnet R., Characterization and analysis of torrefied wood, Wood Sci. Technol. 22 (1988)143-155.

[11] Brown H.P., Panshin A.J., Forsaith C.C., Working stresses for wood, in: Textbook of wood technology, McGraw-Hill, Book company, Inc., New York, Toronto, London, 1952, pp. 474-499.

[12] Burmester A., Einfluss einer Wärme-Druck-Behandlung haldtrockenen Holzes auf seine Formbeständigkeit, Holz Roh- Werkst. 31 (1973) 237-243.

[13] Burmester A., Zur Dimensionsstabilisierung von Holz, Holz RohWerkst. 33 (1975) 333-335.

[14] Davis W.H., Thompson W.S., Influence of thermal treatments of short duration on the toughness and chemical composition of wood, For. Prod. J. 14 (1964) 350-356.

[15] Fengel D., Wegener G., Wood: Chemistry, Ultrastructure, Reactions, Walter de Gruyter and Co. Berlin, New York, 1984.

[16] Garrote G., Dominguez H., Parajo J.C., Hydrothermal processing of lignocellulosic materials. Holz Roh- Werkst. 57 (1999) 191-202.

[17] Giebeler E., Dimensionsstabilisierung von Holz durch eine Feuchte/Wärme/Druck-Behandlung, Holz Roh- Werkst. 41 (1983) 87-94.

[18] Goring D.A.I., Thermal softening of lignin, hemicelluloses and cellulose, Pulp Pap. Mag. Canada 64 (1963) T-517-527.

[19] Hillis W.E., High temperature and chemical effects on wood stability. Part 1. General considerations, Wood Sci. Technol. 18 (1984) 281-293.

[20] Hillis W.E., Rozsa A.N., The softening temperatures of wood, Holzforschung 32 (1978) 69-73.

[21] Hillis W.E., Rozsa A.N., High temperature and chemical effects on wood stability. Part 2. The effect of heat on the softening of radiata pine, Wood Sci. Technol. 19 (1985) 57-66. 
[22] Ifju G., Tensile strength behaviour as a function of cellulose in wood, For. Prod. J. 14 (1964) 366-372.

[23] Kass A., Wangaard F.F., Schroeder H.A., Chemical degradation of wood: the relationship between strength retention and pentosan content, Wood fiber 2 (1970) 31-39.

[24] Kollmann F.F.P., Mechanics and rheology of wood, in: Kollmann F.F.P., Coté W.A. (Eds.), Principles of wood science and technology. I. Solid wood, Springer-Verlag, Berlin, Heidelberg, New York, 1968, pp. 292-414.

[25] Kollmann F., Fengel D., Änderungen der chemischen Zusamensetzung von Holz durch thermische Behandlung, Holz Roh- Werkst. 21 (1965) 77-85.

[26] Kollmann F., Schneider A., Uber dass Sorptionsverhalten wärmebehandelter Hölzer, Holz Roh- Werkst. 41 (1963) 87-94.

[27] Košíková B., Hricovini M., Cosetino C., Interaction of lignin and polysaccharides in beech wood (Fagus sylvatica) during drying processes, Wood Sci. Technol. 33 (1999) 373-380.

[28] Kubojima Y., Okano T., Ohta M., Bending strength and toughness of heat treated wood, J. Wood Sci. 46 (2000) 8-15.

[29] LeVan S.L., Ross R.J., Winandy J.E., Effects of fire retardant chemicals on bending properties of wood at elevated temperatures, Res. Pap. FPL-RP-498, 1990.

[30] Mark R.E., Cell wall mechanics of tracheids, Yale University Press, New Haven, CT, 1967.

[31] McKenzie W.M.C., Design of structural timber, MacMillan Press Ltd, 2000.

[32] Natterer J., Sandoz J.L., Rey M., Construction en bois. Materiau, technologie et dimensionnement, Traité de génie civil, Vol. 13, Presses polytechniques et universitaires Romandes, 2004.

[33] Noack D., Uber die Heisswasserbehandlung von Rotbuchenholz im Temperaturbereich von 100 bis $180^{\circ} \mathrm{C}$, Holzforsch. Holzverwert. 21 (1969) 118-124.

[34] Pizzi A., Stephanou A., Boonstra M.J., Pendlebury A.J., A new concept on the chemical modification of wood by organic anhydrides, Holzforschung 48 (Suppl.) (1994) 91-94.

[35] Pott G., Natural fibers with low moisture sensitivity, in: Natural fibers, plastics and composites, chapter 8, Kluwer Academic Publishers, 2004.

[36] Rowell R.M., Physical and mechanical properties of chemically modified wood, in: Hon D.N.-S. (Ed.), Chemical modification of lignocellulosic materials, M. Dekker, New York, 1996, pp. 295310 .

[37] Rousset P., Turner I., Donnot A., Perré P., Choix d'un modèle de pyrolyse ménagée du bois à l'échelle de la microparticule en vue de la modélisation macroscopique, Ann. For. Sci. 63 (2006) 213-229.

[38] Rusche H., Thermal degradation of wood at temperatures up to $200{ }^{\circ} \mathrm{C}$. Part 1: Strength properties of dried wood after heat treatment, Holz Roh- Werkst. 31 (1973) 273-281.

[39] Sanderman W., Augustin H., Chemical investigations on the thermal decomposition of wood, Part I: Stand of research, Holz RohWerkst. 21 (1963) 256-265.
[40] Scheiding W., Kruse K., Plaschkies K., Weiss B., Thermally modified timber (TMT) for playground toys: Investigations on 13 industrially manufactured products, in: proc. 2nd European conference on Wood modification, Goettingen, Germany, October 2005.

[41] Seborg R.M., Tarkow H., Stamm A.J., Effect of heat upon the dimensional stabilisation of wood, J. For. Prod. Res. Soc. 3 (1953) $59-67$.

[42] Shiraishi N., Wood plasticization, in: Hon D.N.-S., Shiraishi N. (Eds.) Wood and cellulosic chemistry, Marcel Dekker, Inc., New York, Basel, 2001, pp. 655-700.

[43] Sivonen H., Maunu S.L., Sundholm F., Jamsa S., Viitaniemi P., Magnetic resonance studies of thermally modified wood, Holzforschung 56 (2002) 648-654.

[44] Stamm A.J., Wood and cellulose science, Ronald Press Company, USA, 1964.

[45] Sweet M.S., Winandy J.E., The influence of degree of polymerisation (DP) of cellulose and hemicellulose on the strength loss of fire-retardant-treated wood, Holzforschung 53 (1999) 311-317.

[46] Tjeerdsma B.F., Militz H., Chemical changes in hydrothermal treated wood: FTIR analysis of combined hydrothermal and dry heat-treated wood, Holz Roh- Werkst. 63 (2005) 102-111.

[47] Tjeerdsma B.F., Boonstra M., Militz H., Thermal modification of non-durable wood species. Part 2. Improved wood properties of thermally treated wood, International Research Group on Wood Preservation, Document No. IRG/WP 98-40124, 1998.

[48] Tjeerdsma B.F., Boonstra M., Pizzi A., Tekely P., Militz H., Characterisation of thermally modified wood: molecular reasons for wood performance improvement, Holz Roh- Werkst. 56 (1998) 149-153.

[49] Viitaniemi P., Jämsä S., Puun modifionti lampokassittelylla (Modification of wood with heat treatment), Espoo 1996, VTT Juskaisuja - Publikationer 814, 1996.

[50] Weiland J.J., Guyonnet R., Retifiziertes Holz. 16. Verdichter Holzbau in Europa. Motivation, Erfahrung, Entwicklung, in: Dreilander Holztagung. 10. Joanneum Research Fachtage, 2-5 11 1997, Grazer Congress, Grazz, Austria, 1997.

[51] Whistler R.L., Chen C.-C., Hemicelluloses, in: Lewin, Goldstein (Eds.), Wood structure and composition, International fiber science and technology series, Vol. 11, Marcel Decker, Inc., New York, NY, 1991, pp. 287-320.

[52] Winandy J.E., Effects of fire retardant treatments after 18 months of exposure at $150{ }^{\circ} \mathrm{F}\left(66^{\circ} \mathrm{C}\right)$, Res. Note FPL-RN-0264, 1995.

[53] Winandy J.E., Effects of treatment, incising and drying on mechanical properties of wood, Gen. Tech. Rep. FPL-GTR 94: 371-378, 1996.

[54] Winandy J.E., Lebow P.K., Modelling strength loss in wood by chemical composition. Part I. An individual component model for southern pine, Wood fiber Sci. 33 (2001) 239-254.

[55] Winandy J.E., Rowell R.M., The chemistry of wood strength, in: Rowell R.M. (Ed.) The Chemistry of solid wood, American Chemical Society, Washington, DC, 1984, pp. 211-256. 